\title{
Effect of Wheat Germ oil and Coenzyme Q10 on Physiological Performance and Testicular Oxidative Stress Markers in Rabbit Bucks
}

\author{
Eman H. halawa1, Ahmed A.Radwan', Abdelkarim I. M. El-Sayed', Omar A. A. Farid ${ }^{2}$ \\ ${ }^{1}$ Animal ProductionDepartment, Faculty of Agriculture, Benha University, Egypt. \\ 2Physilology Department, National Organization for Drug Control and Research (NODCAR), Giza 12553, Egypt. \\ Corresponding author: Abdelkarim_54@yahoo.com.
}

\begin{abstract}
The aim of this study is to investigate the efficacy of WGO and Coenzyme Q10 low and high doses on physiological performance and testicular oxidative status of male rabbit bucks. In addition tracing the best suitable interval which modulates physiological response under Egyptian summer condition. This experiment was done on a pure strain of Sinai gabali bucks 3 months old. The animals were randomly divided into four groups each one comprise 6 animals. The $1^{\text {st }}$ group served as normal control (C), the $2^{\text {nd }}$ group treated with wheat germ oil (WGO) $(300 \mathrm{mg} / \mathrm{kg} \mathrm{BW})$, the $3^{\text {rd }}$ group treated with Coenzyme Q10L $(10 \mathrm{mg} / \mathrm{kg} \mathrm{BW})$, and the $4^{\text {th }}$ group treated with Coenzyme Q10H $(20 \mathrm{mg} / \mathrm{kg}$ BW).Rabbits of all treatments were given oral administration daily for 60 days, and blood samples were collected monthly along 6 months after the end of the treatment. Moreover, the rabbits were decapitated and the testes tissues were exceed for evaluation Reduced Glutathione (GSH), Malondialdehyde (MDA), Oxidized Glutathione (GSSG) and Nitric oxide (NO) contents. Data revealed that liver function did not show any significant differences due to treatment. Month effect did not show any differences in ALT and AST values. According to the interaction of treatment and month data showed the best value of ALT and AST (26.48 and $32.72 \mathrm{U} / \mathrm{L}$, respectively) in C $\times 6^{\text {th }}$ and Coenzyme Q10L $\times 5^{\text {th }}$ month, respectively. With regard to Lipid profile data showed significant decrease $(\mathrm{P}<0.05)$ of total cholesterol, LDL and triglyceride due to Coenzyme Q10L treatment and significant $(\mathrm{P}<0.05)$ increase in $\mathrm{HDL}$ due to Coenzyme Q10L treatment and the interaction showed the best values for TC, TG, HDL and LDL $(89.50 \mathrm{mg} / \mathrm{dL}$ Coenzyme Q10L $\times 2^{\text {nd }}$ month, $87.50 \mathrm{mg} / \mathrm{dL}$ Coenzyme Q10L $\times 3^{\text {rd }}$ month, $36.00 \mathrm{mg} / \mathrm{dL}$ Coenzyme Q10L $\times 3^{\text {rd }}$ month and $35.96 \mathrm{mg} / \mathrm{dL}$ Coenzyme Q10L $\times 3^{\text {rd }}$ month, respectively). Results did not show any significant $(\mathrm{P}>0.05)$ differences in blood proteins in the 4 groups due to the effect of treatments on male rabbits. Also month effect data did not show any changes $(\mathrm{P}>0.05)$ in blood proteins. The interaction showed the best values of blood proteins, total protein ,albumin ,globulin and $\mathrm{A} / \mathrm{G}$ ratio, $7.63 \mathrm{~g} / \mathrm{dL}$ in Coenzyme $\mathrm{Q} 10 \mathrm{H} \times 4^{\text {th }} \mathrm{month}$ (hot THI), $4.17 \mathrm{~g} / \mathrm{dL}$ in WGO $\times 2^{\text {nd }}$ month (hot THI), $3.58 \mathrm{~g} / \mathrm{dL}$ in Coenzyme Q10H $\times 4^{\text {th }}$ month(hot THI) and 1.30 in Coenzyme Q10H $\times 6^{\text {th }}$ month (mild THI), respectively). Oxidative markers of testicular MDA and GSH showed decreases in MDA and increase in GSH due to WGO and Coenzyme Q10 treatments, respectively. In conclusion, the present study suggests that Coenzyme Q10 and WGO treatments improve physiological performance, reduced heat stress and testicular oxidative stress markers in Sinai gabali male rabbits under Egyptian summer condition.
\end{abstract}

Keywords: Coenzyme Q10, Wheat germ oil, Sinai gabali rabbits, Lipid profile, Oxidative markers.

\section{Introduction}

Heat stress (HS) and oxidative stress often blamed for suboptimal reproductive efficiency and is a worldwide problem, which inflicts heavy economic losses reflected in limiting the breeding season of rabbits to be normally from September to May in northern hemisphere and subtropical regions.

Oxidative stress is defined as the unbalancing between production of free radicals, molecules characterized by high reactivity due to one or more unpaired electrons in the external orbital, and antioxidant defenses in the biological systems. In addition, it is considered an important pathogenetic mechanism in different diseases (Halliwell and Gutteridge, 1979). An augmented ROS production can be the consequence of an augmented electronic flow in the respiratory chain, when it is activated by an increased energetic demand or contribution of substrates (Turrens and Boveris, 1980). There are many substances that used as antioxidants and their role to protect the body against the free radicals. These substances can be liposoluble, such as vitamin E and coenzyme Q10, the only liposoluble antioxidant synthesized in living organisms and herbal extract as wheat germ oil (WGO). WGO contains alpha- and gamma- tocotrienols and induces the tocopherol-mediated redox system and inhibits the synthesis of eicosanoid, which activates the lipid peroxidation process (Paranich et al., 2000).

Coenzyme Q10 (CoQ10), ubiquinone-10, is an important lipid-soluble molecule, which exists in the inner membrane of mitochondria. It works as hydrogen carrier in the respiratory chain and plays an important physiological role. It is not only activates enzymes but also enhances the immunity of organisms. It is an antioxidant that has great importance against free radicals, protects the stability 
of the cell membrane, DNA from free radicals induced oxidative damage and helps recycling of vitamin $\mathrm{E}$ and maintain healthy energy levels. It plays a crucial role in the production of cellular adenosine triphosphate which provides modulating antioxidants defense system. Studies have shown that antioxidants are uniquely different from each other and each have a specific function in the body. They are attracting more and more attention and the range of clinical applications is gradually being expanded (Roffe et al., 2004; Sohmiya et al., 2004; Yalcin et al., 2004).

The aim of this study is to investigate the efficacy of WGO and Coenzyme Q10 low and high doses on physiological performance and testicular oxidative status of male rabbit bucks. In addition tracing the best suitable interval which modulates physiological response under Egyptian summer condition.

\section{Materials and methods}

\section{Experimental design:}

This experiment was done on 24 mature Sinai gabali bucks 3 months old with average weight 1.9 $\pm 0.1 \mathrm{~kg}$. The animals were randomly divided into four groups each one comprise 6 animals. The $1^{\text {st }}$ group served as normal control (C) treated with distilled water $(0.5 \mathrm{~mL} / \mathrm{kg} \mathrm{BW}), 2^{\text {nd }}$ group treated with daily oral dose of wheat germ oil $(300 \mathrm{mg} / \mathrm{kg}$ $\mathrm{BW}), 3^{\text {rd }}$ group treated with daily oral low dose of Coenzyme Q10 (10 $\mathrm{mg} / \mathrm{kg} \mathrm{BW})$, and $4^{\text {th }}$ group treated with daily oral high dose of Coenzyme Q10 (20 mg/kg BW).

\section{Management:}

These animals were housed in animal house of rabbitary farm at cages with wire-mesh bases constructed of galvanized steel. Dimensions of cages were (60 length $\times 40$ width $\times 40 \mathrm{~cm}$ height). All animals were housed in a room with controlled lighting (14 h/day) and natural ventilation. Animals were supplied with adequate standard diet pellets purchased from (IBEX) company with ingredient composition designed from Nutrition Requirement Center (NRC, 1977). The pelleted ration was provided in the morning. Fresh clean water was available at all time. After adaptation period (7 days), animals treated for 60 days under the same conditions of adaptation period.

\section{Blood samples:}

Blood samples from individual animals in each group were withdrawn from the marginal air vein of the ears which visualized and dilated by a warmwash cloth before sampling. The samples were taken using gauge butterfly catheter according to the method of Moore (2000). Blood samples were withdrawn from each animal at zero time (at five months of age, after two months of treatment), and monthly within for next six months. Samples collected from each animal in clear centrifuge tubes and were kept at room temperature for one hour and, half. The tube centrifuged at 3500 r.p.m for $20 \mathrm{~min}$, the supernatant layer for clear serum was carefully withdrawn and kept at $-20{ }^{\circ} \mathrm{C}$ until subsequent analysis.

Testes tissues: At the end of the experiment, the rabbits were decapitated and dissected testes tissues were excides for evaluation a testicular Reduced Glutathione (GSH), Malondialdehyde (MDA), Oxidized Glutathione (GSSG) and Nitric oxide (NO) contents.

\footnotetext{
Ambient temperature, relative humidity and temperature humidity index:

The ambient temperature and relative humidity were obtained daily from Meteorological Authority in Qalioubia throughout the whole experimental period. The temperature humidity index (THI) was calculated during mild and hot months according to Marai et al. (2000) as:

$\mathrm{THI}=\mathrm{db}^{\circ} \mathrm{C}-\left[(0.31-0.31 \mathrm{RH} / 100) \times\left(\mathrm{db}{ }^{\circ} \mathrm{C}-14.4\right)\right]$. Where, $\mathrm{THI}=$ temperature humidity index, $\mathrm{db}^{\circ} \mathrm{C}=$ dry bulb temperature in Celsius and $\mathrm{RH}=$ relative humidity $\div 100$.

A value of THI $<22.2$ was considered remarkably an absence of heat stress, while the values for 22.2 to 23.3 referred to moderate (mild) heat stress, 23.3 to $<25.6$ referred to severe heat stress and $>25.6$ referred to very severe heat stress. Values of THI during the experimental period are presented in Table 1:
}

Table 1. The monthly average temperature, humidity and temperature- humidity index (THI) in the area of farm during the experimental period (May- October, 2017).

\begin{tabular}{lcccc}
\hline Month & $\begin{array}{l}\text { Average of air } \\
\text { temperature }\left({ }^{\circ} \mathbf{C}\right)\end{array}$ & $\begin{array}{l}\text { Average of } \\
\text { humidity (\%) }\end{array}$ & Average of THI & Heat stress \\
\hline May & 27 & 44.86 & 24.84 & Sever \\
June & 29 & 48.73 & 26.67 & Very Sever \\
July & 31 & 53.32 & 28.59 & \\
August & 30.5 & 54.90 & 28.24 & Mild \\
September & 28 & 54.30 & 26.07 & 23.33 \\
October & 25 & 50.79 & & \\
\hline
\end{tabular}




\section{Biochemical parameters:}

Serum total cholesterol was quantified spectrophotometrically using Stanbio Cholesterol Liquid Color ${ }^{\circledR}$ Kit, (Proc. No. 1010) produced by Stanbio Laboratory Inc., Boerne, Texas, USA according to Allain et al. (1974). Serum triglycerides concentrations were quantified spectrophotometrically according to Fossati and Prencipe (1982) by using Stanbio Liquid Color ${ }^{\circledR}$, Triglycerides Kit (Proc. No. 2100) employed from, Stanbio Laboratory Inc., Boerne, Texas, USA. The serum high-density lipoprotein HDL- cholesterol (mg/dL) was determined by the method of Lopez (1977) and the serum low-density lipoprotein LDLcholesterol $(\mathrm{mg} / \mathrm{dL})$ was according to the method of Fossati and Prencipe (1982)and the transaminases enzyme (ALT, AST) activities was preformed according to Reitman and Frankel (1957). Concentration of total protein and albumin was estimated using Biuret method in the presence of alkaline cupric sulfate according to the methods of Dumas et al (1971). Globulin value was obtained by subtracting the value of albumin from the corresponding value of total protein. The albumin to globulin ratio $(\mathrm{A} / \mathrm{G})$ was calculated by dividing $\mathrm{A} / \mathrm{G}$ value and determined the Malondialdhyde (MDA) in testes tissue according to Karatepe (2004). Determination of Oxidized Glutathione (GSSG) and Reduced Glutathione (GSH) in tests tissue detected by using the method of Jayatilleke and Shaw (1993)and the Determination of testes tissue Nitric Oxide (NO) ( $\mu \mathrm{mol} / \mathrm{g}$ tissue) detected by using the method of Papadoyannis et al. (1999).

\section{Statistical analysis:}

Analysis of variance in factorial was carried out using SAS procedure guide (SAS, 2004). According to the following liner model:
$\mathrm{X}_{\mathrm{ijk}}=\boldsymbol{\mu}+\mathrm{T}_{\mathrm{i}}+\mathrm{M}_{\mathrm{j}}+(\mathrm{TM})_{\mathrm{ij}}+\mathrm{e}_{\mathrm{ijk}} \ldots \ldots \ldots \ldots \ldots$ (Model)

Whereas:

$X_{i j}=$ the observation of traits for $i j k^{\text {th }}$ buck, $\mu=$ the overall mean, $T_{i}=$ the effect of the $i^{\text {th }}$ treatments,

$\mathrm{M}_{\mathrm{j}}=$ the effect of the $\mathrm{j}^{\text {th }}$ month, (TM) ${ }_{\mathrm{ij}}=$ the fixed effect of the interaction between the $i^{\text {th }}$ treatments and the $\mathrm{j}^{\text {th }}$ months and $\mathrm{e}_{\mathrm{ij}}=$ random error assumed to be independently and randomly distributed.

Significant differences among means were tested using Duncan multiple rang test (Duncan, 1955).

Data expressed via factorial design and extracted to show significant between groups epically interaction effect

The following linear model was applied for tissues measurements:

$\mathbf{Y i j}=\boldsymbol{\mu}+\boldsymbol{\alpha i}+\mathbf{e i j}$ (Model 2)

Whereas:

Yij= observation measured, $\mu=$ the overall mean, $\alpha \mathrm{i}=$ effect of the $\mathrm{i}^{\text {th }}$ treatment and eij= experimental error assumed to be randomly distributed with IND $\sim(0.62 \mathrm{e})$.

\section{Results and Discussion.}

\section{Liver function:}

Observed data in Figure 1 showed non-significant differences between treatments and control on liver enzymes. It was found that the group of male rabbit which treated with daily oral dose of Coenzyme Q10 (10 mg / kg B.W) revealed non- significant decreases AST and ALT values (34.49 and $27.99 \mathrm{U} / \mathrm{L})$, respectively compared with other treatments. This means that low dose of Coenzyme Q10 and WGO did not affected liver enzymes.

Fig. 1. Effect of wheat germ oil (WGO) and Coenzyme Q10 (CoQ10) on aspartate aminotransferase AST

$(\mathrm{U} / \mathrm{L})$ and alanine aminotransferase ALT (U/L) in male Sinai gabali rabbits after 60 days of treatment .

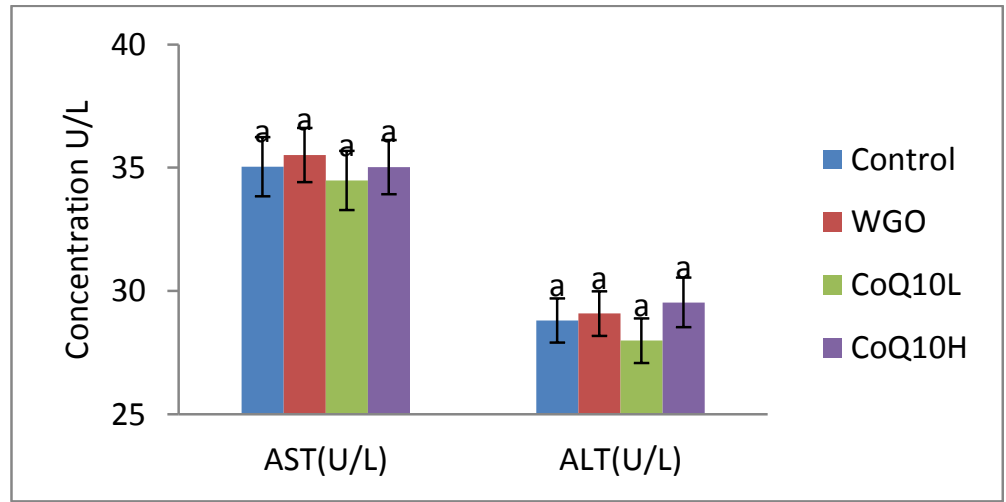

WGO $=$ Wheat GermOil (300mg/Kg B.W), CoQ10 L= $10 \mathrm{mg} / \mathrm{Kg}$ B.W. CoQ10H $=20 \mathrm{mg} / \mathrm{Kg}$ B.W.

Observed data in Figure2 did not show any significant differences between different 6 months in ALT activity the other hand results showed significant differences $(\mathrm{P}<0.05)$ in AST values. These results showed that the least value of AST (33.94 U/L) was in the $5^{\text {th }}$ month of experimental period and the least value of ALT (27.90 $\mathrm{U} / \mathrm{L}$ ) was in the $6^{\text {th }}$ month of experimental period (October). 
Fig. 2: Effect of month on aspartate aminotransferase (AST) and Alanine aminotransferase (ALT) in blood serum of male Sinai gabali rabbits after 60 days of treatment with WGO and Coenzyme Q10.

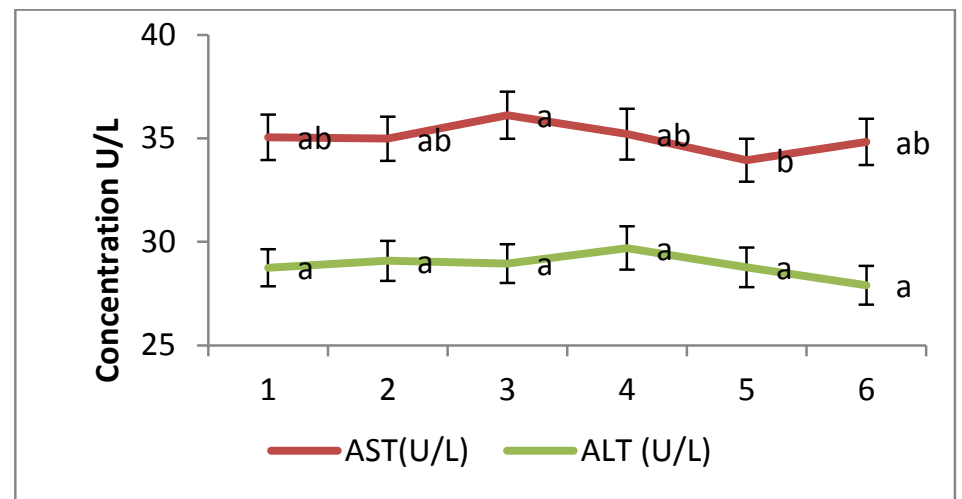

ALT = Alanine aminotransferase, $\mathbf{A S T}=$ Aspartate aminotransferase.

$\mathbf{1}^{\text {st }}=$ May, $\mathbf{2}^{\text {nd }}=$ June, $3^{\text {rd }}=$ July, $\mathbf{4}^{\text {th }}=$ August, $\mathbf{5}^{\text {th }}=$ Septembre, $\mathbf{6}^{\text {th }}=$ Octobre .

According to the interaction between treatment and month, data in Table 2 showed the best value of ALT and AST (26.48 and $32.72 \mathrm{U} / \mathrm{L})$ in $\mathrm{C} \times 6^{\text {th }}$ and Coenzyme $\mathrm{Q} 10 \mathrm{~L} \times 5^{\text {th }}$ month, respectively. And the data showed the lowest measurements of AST in Coenzyme Q10L in the $5^{\text {th }}$ month and the lowest value of ALT was in the control in $6^{\text {th }}$ month
(October, mild THI) with a mean value of $26.48 \mathrm{U} / \mathrm{L}$. These results showed non-significant differences between treatments and control on liver enzymes. This means that Coenzyme Q10 and WGO did not show any pathological alteration in liver and indicated the safety for liver enzymatic-profile after treatment along 2 months.

Table 2. Effect of wheat germ oil (WGO) and Coenzyme Q10 (CoQ10) on aspartate aminotransferase (AST) and alanine aminotransferase (ALT) in blood serum of male Sinai gabali rabbits.

\begin{tabular}{|c|c|c|}
\hline $\begin{array}{l}\text { Interaction } \\
(\text { treatment } \times \text { month })\end{array}$ & AST (U/L) & ALT (U/L) \\
\hline Control $\times 1^{\text {st }} \mathbf{m}$ & $34.3 \pm 1.049 \mathrm{ab}$ & $28.82 \pm 0.914 \mathrm{a}$ \\
\hline WGO $\times 1^{\text {st }} \mathbf{m}$ & $35.57 \pm 1.09 \mathrm{ab}$ & $29.73 \pm 1.059 \mathrm{a}$ \\
\hline CoQ10L $\times 1^{\text {st }} \mathbf{m}$. & $35.11 \pm 1.072 \mathrm{ab}$ & $27.01 \pm 0.888 \mathrm{a}$ \\
\hline $\mathrm{CoQ} 10 \mathrm{H} \times 1^{\text {st }} \mathrm{m}$. & $35.23 \pm 1.114 \mathrm{ab}$ & $29.43 \pm 0.996 a$ \\
\hline Control $\times 2^{\text {nd }} \mathrm{m}$. & $35.13 \pm 1.113 \mathrm{ab}$ & $28.33 \pm 1.007 \mathrm{a}$ \\
\hline WGO $\times 2^{\text {nd }} \mathrm{m}$ & $35.26 \pm 1.102 \mathrm{ab}$ & $30.33 \pm 0.95 a$ \\
\hline CoQ10L $\times 2^{\text {nd }} \mathrm{m}$. & $34.83 \pm 1.157 \mathrm{ab}$ & $27.3 \pm 0.971 \mathrm{a}$ \\
\hline $\mathrm{CoQ} 10 \mathrm{H} \times 2^{\text {nd }} \mathrm{m}$. & $34.68 \pm 1.06 \mathrm{ab}$ & $30.35 \pm 0.921 \mathrm{a}$ \\
\hline Control $\times 3^{\text {rd }} \mathrm{m}$. & $37.33 \pm 1.151 \mathrm{a}$ & $30.53 \pm 1.089 a$ \\
\hline WGO $\times 3^{\text {rd }} \mathrm{m}$ & $36.07 \pm 1.176 \mathrm{ab}$ & $29.85 \pm 1.03 \mathrm{a}$ \\
\hline CoQ10L $\times 3^{\text {rd }} \mathrm{m}$. & $34.72 \pm 1.162 \mathrm{ab}$ & $27.88 \pm 0.936 a$ \\
\hline $\mathrm{CoQ} 10 \mathrm{H} \times 3^{\text {rd }} \mathrm{m}$. & $36.33 \pm 1.27 \mathrm{ab}$ & $27.55 \pm 0.861 \mathrm{a}$ \\
\hline Control $\times 4^{\text {th }} \mathrm{m}$. & $33.9 \pm 1.122 \mathrm{ab}$ & $30.27 \pm 0.917 a$ \\
\hline WGO $\times 4^{\text {th }} \mathrm{m}$ & $36.9 \pm 1.292 \mathrm{a}$ & $30.18 \pm 1.015 \mathrm{a}$ \\
\hline CoQ10L $\times 4^{\text {th }} \mathrm{m}$. & $35.21 \pm 1.2 \mathrm{ab}$ & $28.8 \pm 0.9 \mathrm{a}$ \\
\hline $\mathrm{CoQ} 10 \mathrm{H} \times 4^{\text {th }} \mathrm{m}$. & $34.81 \pm 1.184 \mathrm{ab}$ & $29.53 \pm 0.9 \mathrm{a}$ \\
\hline Control $\times 5^{\text {th }} \mathrm{m}$. & $34.38 \pm 1.11 \mathrm{ab}$ & $28.4 \pm 1.008 \mathrm{a}$ \\
\hline WGO $\times 5^{\text {th }} \mathrm{m}$ & $34.38 \pm 1.102 \mathrm{ab}$ & $27.71 \pm 0.906 a$ \\
\hline CoQ10L $\times 5^{\text {th }} \mathrm{m}$. & $32.72 \pm 1.103 b$ & $28.12 \pm 0.903 a$ \\
\hline $\mathrm{CoQ} 10 \mathrm{H} \times 5^{\text {th }} \mathrm{m}$. & $34.27 \pm 1.08 \mathrm{ab}$ & $30.85 \pm 0.992 \mathrm{a}$ \\
\hline Control $\times 6^{\text {th }} \mathrm{m}$. & $35.23 \pm 1.109 \mathrm{ab}$ & $26.48 \pm 0.849 a$ \\
\hline WGO $\times 6^{\text {th }} \mathrm{m}$ & $34.87 \pm 1.114 \mathrm{ab}$ & $26.76 \pm 0.828 \mathrm{a}$ \\
\hline CoQ10L $\times 6^{\text {th }} \mathrm{m}$. & $34.36 \pm 1.10 \mathrm{ab}$ & $28.82 \pm 0.91 \mathrm{a}$ \\
\hline $\mathrm{CoQ} 10 \mathrm{H} \times 6^{\text {th }} \mathrm{m}$. & $34.81 \pm 1.18 \mathrm{ab}$ & $29.56 \pm 0.88 \mathrm{a}$ \\
\hline
\end{tabular}

Data are expressed as Mean \pm S.E.M for 6 rabbits /group.

Means having different letters in the same column are significantly different at $\mathrm{P}<0.05$.

$\mathrm{WGO}=$ Wheat Germ Oil (300 mg/Kg B.W), CoQ10 L= $10 \mathrm{mg} / \mathrm{Kg} \mathrm{B.W,} \mathrm{CoQ10H} \mathrm{=} 20 \mathrm{mg} / \mathrm{Kg}$ B.W.

$1^{\text {st }} \mathrm{m} .=$ May, $2^{\text {nd }} \mathrm{m} .=$ June, $3^{\text {rd }} \mathrm{m} .=$ July, $4^{\text {th }} \mathrm{m} .=$ August, $5^{\text {th }} \mathrm{m} .=$ Septembre, $6^{\text {th }} \mathrm{m} .=$ Octobre 
The decrease of liver enzymes may be due to the role of stability of Coenzyme Q10 membrane which leads to reduction of ALT and AST leakage from liver. These results are in agreement with the finding of Ali et al. (2010) who suggested that Coenzyme Q10 protected rats against Carbon Tetrachloride(CCl4) induce liver injury. Ubiquinone is an internal synthesized lipid soluble benzo- quinone compound that is found in most living cells in the body act as an expansion electron carrier in the mitochondrial respiratory chain (Forbes et al., 2008).

In the same manner obtained data are in agreement with Pari and Arumugam (2008) who reported that in rats the WGO decrease the levels of serum AST and ALT which indicate the decrease permeability and protect cell damage or necrosis of hepatocytes. In addition, the activities of antioxidant enzymes may have arisen from the individual and synergistic effects of vitamins, fatty acids, phytosterols and phenolic compounds found in wheat germ oil. It is considered that this compound has antioxidant activity, owing to its composition, and has the prospect motivate positive effects on the antioxidant defense system (Paranich et al., 2000; Leenhardt et al., 2008). Liver is the main detoxifying organ in the body, and as such it possesses a high metabolic rate and it is subjected to many insults potentially causative of oxidative stress. Consequently, a correct status of the hepatic antioxidant defense system is of major importance for the maintenance of health according to Mario $\boldsymbol{e t}$ al. (2003).

\section{Lipid profile:}

Obtained data in Figure 3showed a significant decrease in TC, TG and LDL values compared to control and increase in HDL values due to the treatment with Coenzyme Q10 and WGO.

Fig. 3: Effect of Wheat germ oil (WGO) and Coenzyme Q10 (CoQ10) on total cholesterol (TC), triglyceride (TG), high density lipoprotein (HDL) and low density lipoprotein (LDL) in blood serum of male Sinai gabali rabbits after 60 days of treatment.

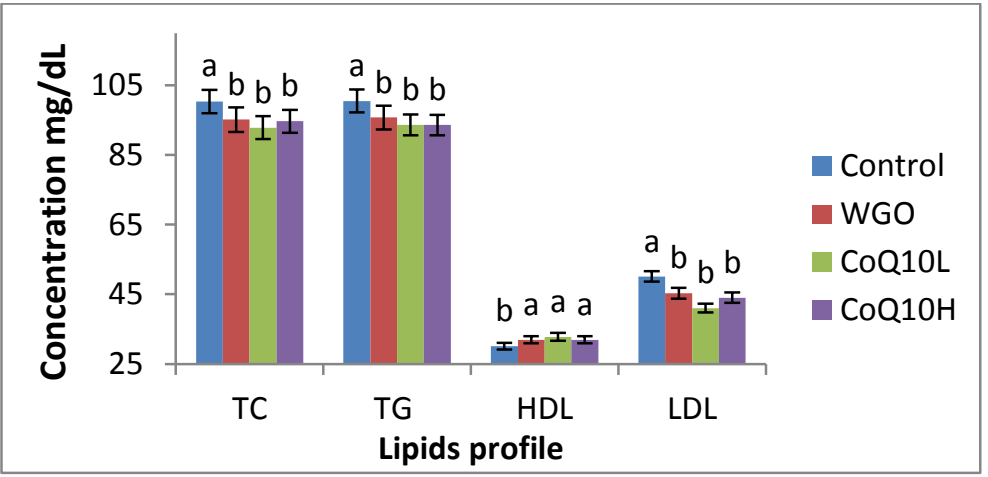

$\mathrm{TC}=$ Total cholesterol, $\mathrm{TG}=$ Triglyceride, $\mathrm{LDL}=\mathrm{Low}$ density lipoprotein, $\mathrm{HDL}=$ high density lipoprotein

$\mathrm{WGO}=$ Wheat germ oil $(300 \mathrm{mg} / \mathrm{Kg} \mathrm{B} . \mathrm{W}), \mathrm{CoQ} 10 \mathrm{~L}=(10 \mathrm{mg} / \mathrm{kg} \mathrm{B} . \mathrm{W}), \mathrm{CoQ} 10 \mathrm{H}=(20 \mathrm{mg} / \mathrm{kg} / \mathrm{B} . \mathrm{W})$

According to the effect of months observed data in Figure 4 showed significant differences $(\mathrm{P}<0.05)$ between different 6 months in lipid profile. These results found the least value of TC $(94.93 \mathrm{mg} / \mathrm{dL})$ was in the $1^{\text {st }}$ month (May) and showed the least value of TG $(93.31 \mathrm{mg} / \mathrm{dL})$ was in the $3^{\text {rd }}$ month (July) and the least value of HDL (29.78 mg/ dL) was in the $5^{\text {th }}$ month (September)of experimental period, while the highest value of HDL $(32.81 \mathrm{mg} /$ dL) was in the $3^{\text {rd }}$ month (July).
According to the interaction between treatment and month data in Table 3 showed the values of lipid profile, where TC recorded the lowest value (89.50 $\mathrm{mg} / \mathrm{dL}$ ) for Coenzyme Q10L $\times 2^{\text {nd }}$ month (June) after two months of treatment, TG least value $(87.50 \mathrm{mg} /$ dL) was in Coenzyme Q10L $\times 3^{\text {rd }}$ month (July), LDL lowest value was $35.96 \mathrm{mg} / \mathrm{dL}$ for Coenzyme Q10L group $\times 3^{\text {rd }}$ month (July), hot month and HDL highest value of HDL was $36.00 \mathrm{mg} / \mathrm{dL}$ in Coenzyme Q10L $\times 3^{\text {rd }}$ month (July). 
Fig. 4: Effect of experimental month on Lipid profile in blood serum of male Sinai gabali rabbits after 60 days of treatment with wheat germ oil (WGO) and Coenzyme Q10 (CoQ10) and.

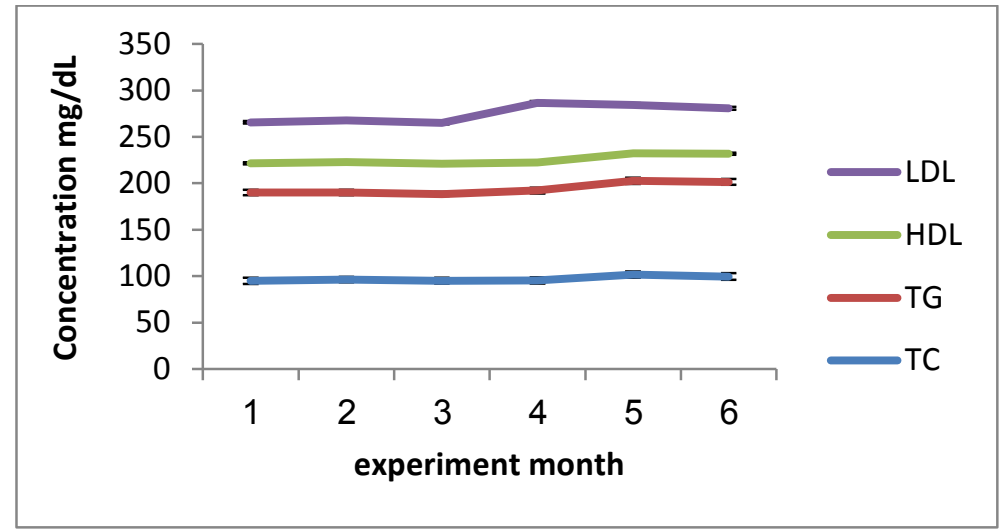

$\mathbf{T C}=$ Total cholesterol, $\mathbf{T G}=$ Triglyceride, $\mathbf{H D L}=$ High density lipoprotein, $\mathbf{L D L}=$ Low density lipoprotein $\mathbf{1}^{\text {st }}$ $=$ May, $\mathbf{2}^{\text {nd }}=$ June, $\mathbf{3}^{\text {rd }}=$ July, $\mathbf{4}^{\text {th }}=$ August, $\mathbf{5}^{\text {th }}=$ September, $\mathbf{6}^{\text {th }}=$ October.

The decrease of lipid profile may be due to the monounsaturated fatty acid which reduces serum lipid profile level. These results are in agreement with Mensink and Katan, (1987), salmeron et al. (1997) and Jenkins et al. (1999); and), who reported that the administration of WGO could reduce the level of lipid profile when compared with the control value. In addition, WGO has a number of other nutritional and health benefits factors like high content of vitamin E and phytosterol (Jonnala et al., 2005) which may be the reason of its lowering effect on triglyceride, cholesterol and LDL. Thus the reduction effect of WGO on triglyceride, cholesterol and LDL and increasing HDL level is a positive finding of this study.

The fatty acid composition of wheat germ oil unsaturated and multiple saturated fatty acid satrates of $81 \%$ and $64 \%$, respectively (Zacchi et al., 2006; Eisenmenger and Dunford, 2008). These fatty acids, alfa-linolenic acid, in relation to its antiinflammatory effect, decreases $\mathrm{O} 2$ - production and NADPH oxidase activity, and thereby, has antioxidant activity (Alessandri $\boldsymbol{e t}$ al., 2011). These compounds are the portent of prostaglandins, which are embroiled in muscle constriction and the speedy recuperation of the inflammatory process. Furthermore, linoleic acid aids in the abstraction of cholesterol and acts as the precursor of cell membrane phospholipids (Zacchiet al., 2006; Piraset al., 2009). Wheat germ oil also contains phytosterols, mainly campesterol, beta-cytosterol, and to a less extent, 5-stigmasterol, 7-stigmassterol, isofucosterol, 7-avenasteroland D5-avenasterol. These compounds, in particular D5-avenasterol has strong antioxidant activity (Malecka, 2002;
Hassanein and Abedel-Razek, 2009). Steryl glycosides constitute another component to the structure of wheat germ oil, with isofuco-SG, campestigma-SG and B-cyto- SG sharing the highest levels (Hassanein and Abedel-Razek, 2009). It is known that the phenolic compounds found in this oil also have antioxidant effect (Niu et al., 2011). Flavonoids are also thought to enhance the efficiency of liver cells to remove LDL from the blood circulation by increasing LDL receptor densities in the liver and binding to a poli- protein B (ElBeshbishy et al., 2006).

In the same manner oral administration with Coenzyme Q10 enhances lipids profile by increasing consumption leading to a lower absorption rate of Coenzyme Q10, as roughly $60 \%$, of oral dosage forms are excreted in the feces (Potgieter, et al., 2013). Plasma Coenzyme Q10 concentrations increase with increasing doses of Coenzyme Q10 at $2,400 \mathrm{mg}$, with a decreased efficiency of absorption at higher dosages. Either during absorption or after absorption, Coenzyme Q10 is reduced to ubiquinol and incorporated into chylomicrons and transported to the liver (Bhagavan and Chopra, 2006). Lastly, these are packaged into lipoprotein particles and released into circulation (Potgieter, et al., 2013). Plasma Coenzyme Q10 is mainly packaged into very low-density lipoprotein VLDL and LDL particles, with a small amount incorporated into high-density lipoprotein (HDL) particles. Among its many functions, it transports mechanism of Coenzyme Q10 along with $\alpha$-tocopherol that protects lipoproteins from lipid peroxidation. (Bhagavan and Chopra, 2006). 
Table 3. Effect of wheat germ oil (WGO) and coenzyme Q10 (CoQ10) on total cholesterol, triglyceride (TG), LDL and HDL in blood serum of male Sinai gabali rabbits after 60 days of treatment.

\begin{tabular}{|c|c|c|c|c|}
\hline $\begin{array}{l}\text { Interaction(treatment } \\
\times \text { month) }\end{array}$ & $\begin{array}{l}\text { Cholesterol } \\
(\mathrm{mg} / \mathrm{dL})\end{array}$ & $\begin{array}{l}\text { Triglyceride } \\
(\mathrm{mg} / \mathrm{dL})\end{array}$ & $\begin{array}{l}\text { HDL } \\
(\mathrm{mg} / \mathrm{dL})\end{array}$ & $\begin{array}{l}\text { LDL } \\
(\mathrm{mg} / \mathrm{dL})\end{array}$ \\
\hline Control $\times 1^{\text {st }} \mathrm{m}$ & $98.12 \pm 3.458 \mathrm{bc}$ & $100.37 \pm 3.074 \mathrm{a}$ & $27.75 \pm 0.933 \mathrm{e}$ & $50.26 \pm 1.586 \mathrm{abc}$ \\
\hline WGO $\times 1^{\text {st }} \mathbf{m}$ & $100.37 \pm 3.505 \mathrm{abc}$ & $98.75 \pm 3.233 \mathrm{a}$ & $30 \pm 0.986 \mathrm{de}$ & $50.62 \pm 1.56 a b c$ \\
\hline CoQ10L $\times 1^{\text {st }} \mathrm{m}$ & $90.37 \pm 3.136 \mathrm{~d}$ & $89.12 \pm 2.821 b$ & $34.37 \pm 1.176 \mathrm{ab}$ & $37.86 \pm 1.167 \mathrm{e}$ \\
\hline $\mathrm{CoQ10H} \times 1^{\text {st }} \mathrm{m}$ & $90.87 \pm 2.922 \mathrm{~d}$ & $91.62 \pm 3.188 b$ & $34 \pm 1.211 \mathrm{abc}$ & $38.4 \pm 1.295 \mathrm{e}$ \\
\hline Control $\times 2^{\text {nd }} \mathrm{m}$. & $102.5 \pm 3.451 \mathrm{ab}$ & $97.87 \pm 3.047 \mathrm{a}$ & $31.37 \pm 0.953 \mathrm{bcd}$ & $51.45 \pm 1.59 \mathrm{abc}$ \\
\hline WGO $\times 2^{\text {nd }} m$ & $103.62 \pm 3.31 \mathrm{ab}$ & $98 \pm 3.185 \mathrm{a}$ & $29.62 \pm 0.963 \mathrm{de}$ & $45.42 \pm 1.56 \mathrm{ab}$ \\
\hline CoQ10L $\times 2^{\text {nd }} \mathrm{m}$. & $89.5 \pm 3.144 \mathrm{~d}$ & $91 \pm 3.116 b$ & $34 \pm 1.184 \mathrm{abc}$ & $37.53 \pm 1.278 \mathrm{e}$ \\
\hline $\mathrm{CoQ10H} \times 2^{\text {nd }} \mathrm{m}$. & $90.12 \pm 3.04 \mathrm{~d}$ & $87.75 \pm 2.66 b$ & $35.5 \pm 1.217 \mathrm{a}$ & $37.01 \pm 1.124 \mathrm{e}$ \\
\hline Control $\times 3^{\text {rd }} \mathrm{m}$. & $100.12 \pm 3.523 \mathrm{abc}$ & $98.75 \pm 3.027 \mathrm{a}$ & $30 \pm 0.967 \mathrm{de}$ & $50.28 \pm 1.762 \mathrm{abc}$ \\
\hline WGO $\times 3^{\text {rd }} \mathrm{m}$ & $99.5 \pm 3.269 \mathrm{bc}$ & $98.25 \pm 2.981 \mathrm{a}$ & $31.25 \pm 0.99 \mathrm{bcde}$ & $48.76 \pm 1.486 \mathrm{bc}$ \\
\hline CoQ10L $\times 3^{\text {rd }} \mathrm{m}$. & $89.62 \pm 2.975 \mathrm{~d}$ & $87.5 \pm 2.822 b$ & $36 \pm 1.165 \mathrm{a}$ & $35.96 \pm 1.282 \mathrm{e}$ \\
\hline $\mathrm{CoQ} 10 \mathrm{H} \times 3^{\text {rd }} \mathrm{m}$. & $91.37 \pm 3.139 \mathrm{~d}$ & $88.75 \pm 2.901 \mathrm{~b}$ & $34 \pm 1.04 \mathrm{abc}$ & $39.62 \pm 1.299 \mathrm{e}$ \\
\hline Control $\times 4^{\text {th }} \mathrm{m}$. & $103 \pm 3.184 \mathrm{ab}$ & $102.87 \pm 3.163 \mathrm{a}$ & $32 \pm 1.117 \mathrm{bcd}$ & $50.12 \pm 1.531 \mathrm{abc}$ \\
\hline WGO $\times 4^{\text {th }} \mathrm{m}$ & $100.75 \pm 3.595 a b c$ & $101.25 \pm 3.109 \mathrm{a}$ & $27.75 \pm 0.965 \mathrm{e}$ & $52.66 \pm 1.642 a b c$ \\
\hline CoQ10L $\times 4^{\text {th }} \mathrm{m}$. & $88.75 \pm 2.835 \mathrm{~d}$ & $91.5 \pm 3.158 \mathrm{~b}$ & $30.87 \pm 1.01 \mathrm{cde}$ & $39.66 \pm 1.267 \mathrm{e}$ \\
\hline $\mathrm{CoQ} 10 \mathrm{H} \times 4^{\text {th }} \mathrm{m}$. & $89.62 \pm 3.019 \mathrm{~d}$ & $91.25 \pm 2.825 b$ & $29.37 \pm 1 \mathrm{de}$ & $42.03 \pm 1.438 \mathrm{de}$ \\
\hline Control $\times 5^{\text {th }} \mathrm{m}$. & $100 \pm 3.438 \mathrm{abc}$ & $102 \pm 3.444 \mathrm{a}$ & $29.25 \pm 0.9 \mathrm{de}$ & $52.25 \pm 1.614 \mathrm{abc}$ \\
\hline WGO $\times 5^{\text {th }} \mathrm{m}$ & $100 \pm 3.26 \mathrm{abc}$ & $99.5 \pm 3.065 \mathrm{a}$ & $30.37 \pm 1.054 \mathrm{de}$ & $49.92 \pm 1.705 \mathrm{abc}$ \\
\hline CoQ10L $\times 5^{\text {th }} \mathrm{m}$. & $100.62 \pm 3.58 \mathrm{abc}$ & $102.12 \pm 3.56 \mathrm{a}$ & $30.25 \pm 0.929 \mathrm{de}$ & $50.13 \pm 1.629 \mathrm{abc}$ \\
\hline $\mathrm{CoQ} 10 \mathrm{H} \times 5^{\text {th }} \mathrm{m}$ & $105 \pm 3.52 \mathrm{a}$ & $99.37 \pm 3.137 \mathrm{a}$ & $29.25 \pm 0.929 \mathrm{de}$ & $55.96 \pm 1.833 \mathrm{a}$ \\
\hline Control $\times 6^{\text {th }} \mathrm{m}$ & $96.75 \pm 3.35 \mathrm{c}$ & $101.12 \pm 3.61 \mathrm{a}$ & $30.12 \pm 1.04 \mathrm{de}$ & $46.41 \pm 1.407 \mathrm{~cd}$ \\
\hline WGO $\times 6^{\text {th }} \mathrm{m}$ & $102.87 \pm 3.23 \mathrm{ab}$ & $102.75 \pm 3.316 \mathrm{a}$ & $30.62 \pm 0.987 \mathrm{cde}$ & $51.5 \pm 1.573 \mathrm{abc}$ \\
\hline CoQ10L $\times 6^{\text {th }} \mathrm{m}$. & $98 \pm 3.148 b c$ & $100.62 \pm 3.561 \mathrm{a}$ & $31.25 \pm 0.961 \mathrm{bcde}$ & $46.67 \pm 1.421 \mathrm{~cd}$ \\
\hline $\mathrm{CoQ} 10 \mathrm{H} \times 6^{\text {th }} \mathrm{m}$. & $101.12 \pm 3.431 \mathrm{abc}$ & $102.75 \pm 3.573 \mathrm{a}$ & $29.37 \pm 0.897 \mathrm{de}$ & $51.11 \pm 1.817 \mathrm{abc}$ \\
\hline
\end{tabular}

Data are expressed as Mean \pm S.E.M for 6 rabbits /group.

Means having different letters in the same column are significantly different at $\mathrm{P}<0.05$.

$\mathrm{WGO}=$ WheatGermOil (300 mg/Kg B.W), CoQ10 L= $10 \mathrm{mg} / \mathrm{Kg}$ B.W, CoQ10H $=20 \mathrm{mg} / \mathrm{Kg}$ B.W.

$1^{\text {st }} \mathrm{m} .=$ May, $2^{\text {nd }} \mathrm{m} .=$ June, $3^{\text {rd }} \mathrm{m} .=$ July, $4^{\text {th }} \mathrm{m} .=$ August, $5^{\text {th }} \mathrm{m} .=$ Septembre, $6^{\text {th }} \mathrm{m} .=$ OctobreTC $=$ Total cholesterol, $\mathrm{TG}=$ Triglyceride, $\mathrm{HDL}=$ High density lipoprotein, $\mathrm{LDL}=$ Low density lipoprotein

Protein factions:

Data in Figure 5 did not show any significant changes in blood proteins due to the treatments with WGO and Coenzyme Q10. This means that Coenzyme Q10 and WGO did not affectin blood proteins.

Fig. 5. Effect of wheat germ oil (WGO) and coenzyme Q10 onTotal protein, Albumin, Globulin g/dL and A/G ratio in blood serum of Sinai gabali rabbits after 60 days.

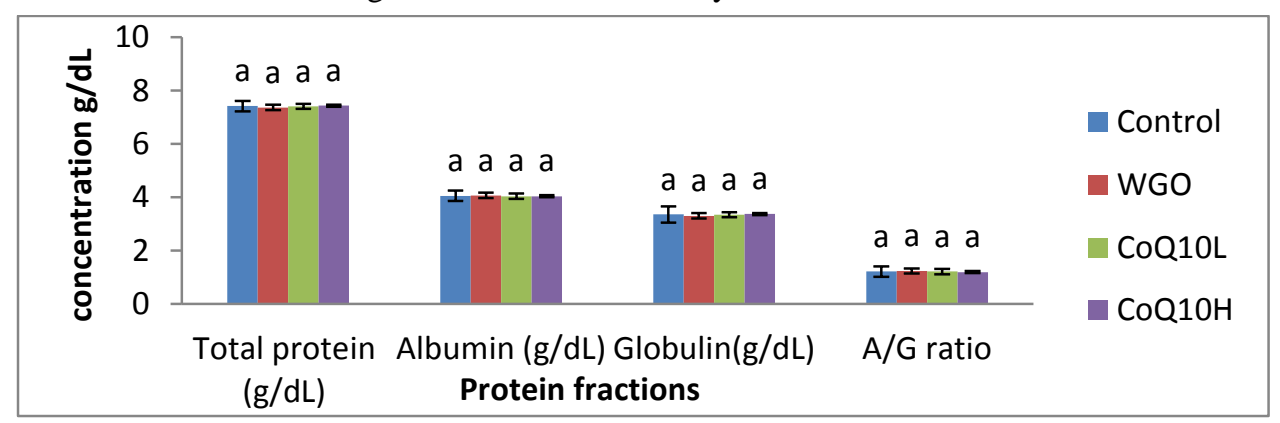

$\mathbf{T P}=$ Total protein, Alb = Albumin, Glob = Globulin.

WGO= Wheat germ oil (300mg/Kg B.W), CoQ10L = Q10 (10mg/kg B.W),

CoQ10H= $(20 \mathrm{mg} / \mathrm{kg} / \mathrm{B} . \mathrm{W})$.

Data in Figure 6 did not show any significant changes in blood proteins in different 6 months after 60 days of treatment. 
Fig. 6: Effect of experiment month on blood serum proteins (Total protein (TP), Albumin (Alb), Globulin (Glob) and A/G ratio) in male Sinai gabali rabbits after 60 days of treatment with wheat germ oil and Coenzyme Q10.

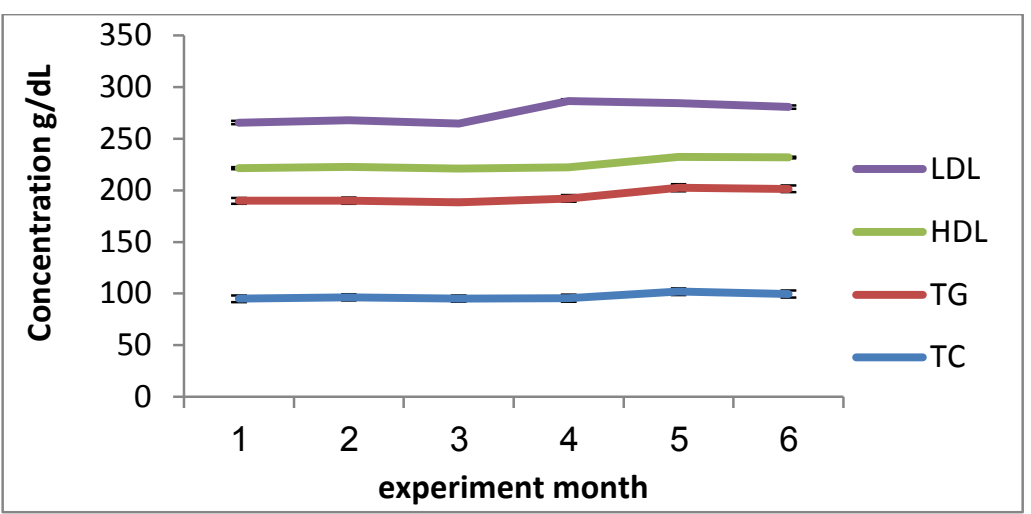

$\mathbf{1}^{\text {st }}=$ May, $\mathbf{2}^{\text {nd }}=$ June, $\mathbf{3}^{\text {rd }}=$ July, $4^{\text {th }}=$ August, $\mathbf{5}^{\text {th }}=$ September, $\mathbf{6}^{\text {th }}=$ October.

Data in Table 4showed the means of interaction between treatment and months and showed the highest values of total protein, albumin, globulin and $\mathrm{A} / \mathrm{G}$ ratio were $7.63 \mathrm{~g} / \mathrm{dL}$ in Coenzyme $\mathrm{Q} 10 \mathrm{H} \times 4^{\text {th }}$ month (August), $4.17 \mathrm{~g} / \mathrm{dL}$ in WGO $\times 2^{\text {nd }}$ month (June), $3.58 \mathrm{~g} / \mathrm{dL}$ in Coenzyme $\mathrm{Q} 10 \mathrm{H} \times 4^{\text {th }}$ month (August) and 1.30 in Coenzyme $\mathrm{Q} 10 \mathrm{H} \times 6^{\text {th }}$ month (October), respectively.

Observed data in Table 4did not show any satisfactory changes in blood proteins. This means that oral administration with Coenzyme Q10or WGO did not affect the vital processes in the body and did not affect the proportion of blood proteins created in the body, may be due to the improvement in protein synthesis in the liver as a result of antioxidant effect which act as a free radical and could protect against lipid peroxidation according to Abd El Dayem and Moawad, (2001).

\section{Oxidative stress markers:}

Data in Table 5 showed the effect of WGO and Coenzyme Q10 on oxidative stress markers in testes tissues in rabbit bucks. The results showed decreases in GSSG and NO due to the treatment with WGO and Coenzyme Q10H, while there was a nonsignificant change in Coenzyme Q10L. Also this study showed a significant decrease in testes tissue oxidative stress marker MDA and increase GSH that may be due to Coenzyme Q10 and WGO antioxidant activity. Bentinger et al. (2007) found that Lipid peroxidation triggers the denaturation of cell membrane, causing increased cell permeability, enzyme inactivation, and structural damage led to DNA mutations, and cell death. It could be involved in the protection of cell membranes from oxidative insult. Coenzyme Q10 shows effectiveness in counteracting free radicals-induced tissue damage. Antiradical effects of Coenzyme Q10 may prevent the initiation and propagation of lipid peroxidation in cellular membranes. Our results are similar to Mohammad et al. (2015) who found that Coenzyme Q10 synergistically all eviate Aluminum induced suppression of testicular Steroidogenesis and antioxidant defense.

Table 4. Effect of wheat germ oil (WGO) and coenzyme Q10 (CoQ10) on blood serum total Protein (TP), Albumin (Alb), globulin (Glob) and A/G ratio in male Sinai gabali rabbits after 60 days of

Treatment.

\begin{tabular}{|c|c|c|c|c|}
\hline $\begin{array}{l}\text { Interaction (month } x \\
\text { treatment }\end{array}$ & $\begin{array}{l}\text { Total protein } \\
\text { (g/dL) }\end{array}$ & $\begin{array}{l}\text { Albumin } \\
(\mathrm{g} / \mathrm{dL})\end{array}$ & $\begin{array}{l}\text { Globulin } \\
\text { (g/dL) }\end{array}$ & A/G ratio \\
\hline Control $\times 1^{\text {st }} \mathbf{m}$ & $7.58 \pm 0.255 \mathrm{ab}$ & $4.1 \pm 0.14 \mathrm{abc}$ & $3.5 \pm 0.11 \mathrm{a}$ & $1.2 \pm 0.039 \mathrm{a}$ \\
\hline WGO $\times 1^{\text {st }} \mathbf{m}$ & $7.38 \pm 0.258 \mathrm{abc}$ & $4.07 \pm 0.14 \mathrm{abc}$ & $3.3 \pm 0.104 \mathrm{a}$ & $1.26 \pm 0.039 \mathrm{a}$ \\
\hline CoQ10L $\times 1^{\text {st }} \mathbf{m}$ & $7.45 \pm 0.237 \mathrm{abc}$ & $4 \pm 0.126 \mathrm{abc}$ & $3.43 \pm 0.106 \mathrm{a}$ & $1.17 \pm 0.038 \mathrm{a}$ \\
\hline $\mathrm{CoQ} 10 \mathrm{H} \times 1^{\mathrm{st}} \mathrm{m}$. & $7.51 \pm 0.253 \mathrm{abc}$ & $3.96 \pm 0.137 \mathrm{cb}$ & $3.53 \pm 0.12 \mathrm{a}$ & $1.12 \pm 0.035 \mathrm{a}$ \\
\hline Control $\times 2^{\text {nd }} \mathrm{m}$. & $7.33 \pm 0.245 \mathrm{abc}$ & $4.02 \pm 0.132 \mathrm{abc}$ & $3.35 \pm 0.102 \mathrm{a}$ & $1.22 \pm 0.043 \mathrm{a}$ \\
\hline WGO $\times 2^{\text {nd }} m$ & $7.52 \pm 0.239 \mathrm{abc}$ & $4.17 \pm 0.141 \mathrm{a}$ & $3.37 \pm 0.105 \mathrm{a}$ & $1.23 \pm 0.042 \mathrm{a}$ \\
\hline CoQ10L $\times 2^{\text {nd }} \mathrm{m}$. & $7.28 \pm 0.25 \mathrm{abc}$ & $3.95 \pm 0.126 c$ & $3.32 \pm 0.109 a$ & $1.2 \pm 0.041 \mathrm{a}$ \\
\hline $\mathrm{CoQ} 10 \mathrm{H} \times 2^{\text {nd }} \mathrm{m}$. & $7.48 \pm 0.254 \mathrm{abc}$ & $3.98 \pm 0.124 \mathrm{cb}$ & $3.45 \pm 0.105 \mathrm{a}$ & $1.16 \pm 0.041 \mathrm{a}$ \\
\hline Control $\times 3^{\text {rd }} \mathrm{m}$ & $7.51 \pm 0.231 \mathrm{abc}$ & $4.05 \pm 0.142 \mathrm{abc}$ & $3.46 \pm 0.111 \mathrm{a}$ & $1.18 \pm 0.042 \mathrm{a}$ \\
\hline WGO $\times 3^{\text {rd }} \mathrm{m}$ & $7.2 \pm 0.254 \mathrm{c}$ & $3.98 \pm 0.123 b c$ & $3.2 \pm 0.105 \mathrm{a}$ & $1.26 \pm 0.041 \mathrm{a}$ \\
\hline CoQ10L $\times 3^{\text {rd }} \mathrm{m}$. & $7.26 \pm 0.256 b c$ & $4.06 \pm 0.145 \mathrm{abc}$ & $3.21 \pm 0.115 \mathrm{a}$ & $1.27 \pm 0.041 \mathrm{a}$ \\
\hline $\mathrm{CoQ} 10 \mathrm{H} \times 3^{\text {rd }} \mathrm{m}$. & $7.3 \pm 0.223 a b c$ & $4.01 \pm 0.132 \mathrm{abc}$ & $3.28 \pm 0.112 \mathrm{a}$ & $1.21 \pm 0.043 \mathrm{a}$ \\
\hline Control $\times 4^{\text {th }} \mathrm{m}$. & $7.26 \pm 0.233 \mathrm{bc}$ & $4.05 \pm 0.128 \mathrm{abc}$ & $3.2 \pm 0.114 \mathrm{a}$ & $1.27 \pm 0.039 \mathrm{a}$ \\
\hline WGO $\times 4^{\text {th }} \mathrm{m}$ & $7.31 \pm 0.224 \mathrm{abc}$ & $4.08 \pm 0.128 \mathrm{abc}$ & $3.25 \pm 0.107 \mathrm{a}$ & $1.27 \pm 0.041 \mathrm{a}$ \\
\hline
\end{tabular}




\begin{tabular}{|c|c|c|c|c|}
\hline $\operatorname{CoQ10L} \times 4^{\text {th }} \mathrm{m}$. & $7.57 \pm 0.239 \mathrm{ab}$ & $4.1 \pm 0.144 \mathrm{abc}$ & $3.47 \pm 0.118 a$ & $1.18 \pm 0.042 \mathrm{a}$ \\
\hline $\mathrm{CoQ} 10 \mathrm{H} \times 4^{\text {th }} \mathrm{m}$. & $7.63 \pm 0.272 \mathrm{a}$ & $4.05 \pm 0.128 \mathrm{abc}$ & $3.58 \pm 0.113 \mathrm{a}$ & $1.15 \pm 0.037 \mathrm{a}$ \\
\hline Control $\times 5^{\text {th }} \mathrm{m}$. & $7.41 \pm 0.25 \mathrm{abc}$ & $4.11 \pm 0.136 \mathrm{abc}$ & $3.28 \pm 0.106 \mathrm{a}$ & $1.26 \pm 0.041 \mathrm{a}$ \\
\hline WGO $\times 5^{\text {th }} \mathrm{m}$ & $7.52 \pm 0.232 \mathrm{abc}$ & $4.01 \pm 0.126 \mathrm{abc}$ & $3.52 \pm 0.107 \mathrm{a}$ & $1.13 \pm 0.037 \mathrm{a}$ \\
\hline CoQ10L $\times 5^{\text {th }} \mathrm{m}$. & $7.4 \pm 0.26 \mathrm{abc}$ & $4.1 \pm 0.126 \mathrm{abc}$ & $3.32 \pm 0.101 \mathrm{a}$ & $1.25 \pm 0.041 \mathrm{a}$ \\
\hline $\mathrm{CoQ} 10 \mathrm{H} \times 5^{\text {th }} \mathrm{m}$ & $7.38 \pm 0.235 \mathrm{abc}$ & $4.12 \pm 0.144 \mathrm{abc}$ & $3.27 \pm 0.107 \mathrm{a}$ & $1.28 \pm 0.041 \mathrm{a}$ \\
\hline Control $\times 6^{\text {th }} \mathrm{m}$. & $7.45 \pm 0.265 \mathrm{abc}$ & $4.02 \pm 0.139 \mathrm{abc}$ & $3.41 \pm 0.108 \mathrm{a}$ & $1.18 \pm 0.036 \mathrm{a}$ \\
\hline WGO $\times 6^{\text {th }} \mathrm{m}$ & $7.32 \pm 0.244 \mathrm{abc}$ & $4.13 \pm 0.126 \mathrm{ab}$ & $3.21 \pm 0.108 \mathrm{a}$ & $1.28 \pm 0.041 \mathrm{a}$ \\
\hline CoQ10L $\times 6^{\text {th }} \mathrm{m}$. & $7.45 \pm 0.245 \mathrm{abc}$ & $4.07 \pm 0.126 \mathrm{abc}$ & $3.37 \pm 0.112 \mathrm{a}$ & $1.23 \pm 0.038 \mathrm{a}$ \\
\hline $\mathrm{CoQ} 10 \mathrm{H} \times 6^{\text {th }} \mathrm{m}$. & $7.32 \pm 0.226 \mathrm{abc}$ & $4.13 \pm 0.143 \mathrm{ab}$ & $3.2 \pm 0.111 \mathrm{a}$ & $1.3 \pm 0.04 \mathrm{a}$ \\
\hline
\end{tabular}

Data are expressed as Mean \pm S.E.M for 6 rabbits /group.

Means having different letters in the same row are significantly different at $\mathrm{P}<0.05$.

WGO = Wheat Germ Oil (300 mg/Kg B.W), CoQ10 L= 10 mg/ Kg B.W, CoQ10H = 20 mg/Kg B.W.

$1^{\text {st }} \mathrm{m} .=$ May, $2^{\text {nd }} \mathrm{m} .=$ June, $3^{\text {rd }} \mathrm{m} .=$ July, $4^{\text {th }} \mathrm{m} .=$ August, $5^{\text {th }} \mathrm{m} .=$ Septembre, $6^{\text {th }} \mathrm{m} .=$ Octobre $)$

$\mathrm{TP}=$ Total protein, $\mathrm{Alb}=$ Albumin, Glob = Globulin.

Table 5. Effects of Wheat germ oil (WGO) Co-enzymeQ10 (CoQ10) on oxidative stress markers

Reduced Glutathione (GSH), Nitric Oxide (NO), Oxidized Glutathione (GSSG) and Malondialdehyde (MDA) in testes tissue of male Sinai gabali rabbits.

\begin{tabular}{lllll}
\hline groups & $\begin{array}{l}\text { GSH } \\
\boldsymbol{\mu m o l} / \mathbf{g} \text { tissue }\end{array}$ & $\begin{array}{l}\text { NO } \\
\boldsymbol{\mu m o l} / \mathbf{g} \text { tissue }\end{array}$ & $\begin{array}{l}\text { GSSG } \\
\boldsymbol{\mu m o l} / \mathbf{g} \text { tissue }\end{array}$ & $\begin{array}{l}\text { MDA } \\
\text { nmol / g tissue }\end{array}$ \\
\hline Control & $17.72 \pm 1.15 \mathrm{c}$ & $0.41 \pm 0.03 \mathrm{a}$ & $0.44 \pm 0.04 \mathrm{a}$ & $25.43 \pm 2.67 \mathrm{a}$ \\
WGO & $28.26 \pm 2.33 \mathrm{a}$ & $0.31 \pm 0.03 \mathrm{~b}$ & $0.28 \pm 0.02 \mathrm{~b}$ & $20.22 \pm 1.34 \mathrm{bc}$ \\
CoQ10L & $17.78 \pm 1.17 \mathrm{c}$ & $0.48 \pm 0.04 \mathrm{a}$ & $0.52 \pm 0.04 \mathrm{a}$ & $23.41 \pm 2.67 \mathrm{ab}$ \\
CoQ10H & $24.36 \pm 1.78 \mathrm{~b}$ & $0.28 \pm 0.02 \mathrm{~b}$ & $0.29 \pm 0.03 \mathrm{~b}$ & $19.69 \pm 1.37 \mathrm{c}$ \\
\hline
\end{tabular}

Data are expressed as Mean \pm S.E.M for 6 rabbits /group.

Means having different letters in the same column are significantly different at $\mathrm{P}<0.05$.

$\mathrm{WGO}=$ Wheat germ oil $(300 \mathrm{mg} / \mathrm{Kg} \mathrm{B} . \mathrm{W}), \mathrm{CoQ} 10 \mathrm{~L}=(10 \mathrm{mg} / \mathrm{kg} \mathrm{B} . \mathrm{W}), \mathrm{CoQ} 10 \mathrm{H}=(20 \mathrm{mg} / \mathrm{kg} / \mathrm{B} . \mathrm{W})$.

Obtained data in Table 5are consisted with Lee $\boldsymbol{e t}$ al. (2011) who found that, Coenzyme Q10 supplementation reduces oxidative stress and increase up regulation of antioxidant enzymes activity in patients with coronary artery disease. Increase ATP production for Coenzyme Q10 may be due to the role of Coenzyme Q10 in mitochondrial respiratory chain (MRC) to synthesize ATP via oxidative phosphorylation. MRC is consists of 5 enzymes complex I-V. Coenzyme Q10 is the predominant form of ubiquinone and serves as an electron carrier in MRC (Rahman and Hanna, 2009).Goel et $\boldsymbol{a l}$. (2005) reported that highly reactive oxygen metabolites, especially hydroxyl radicals, act on unsaturated fatty acids of phospholipid components of membranes to produce malondialdehyde, a lipid peroxidation product. This is in the same trend with our results which reported to induce oxidative stress, as shown by enhanced MDA production and decrease GSH.

\section{Conclusion}

The results of the present study indicate that administration of WGO or Coenzyme Q10presented positive effects of reduced total cholesterol, triglycerides, low density lipoprotein and increased high density lipoprotein, also the data showed that oral administration of WGO and Coenzyme Q10 did not affect Total protein, Albumin, Globulin and A/G ratio, liver functions (AST and ALT) and decrease testicular oxidative marker MDA, GSSG, NO and increase GSH.in addition air temperature did not affect on physiological performance due to the use of antioxidants.

\section{References}

Abd El-Dayem, S.M. and K.M. Moawad, 2001. Toxicity of CCL4 in rat liver and the effects of antioxidant treatments. J. Egypt. Soc. Zool., 36: 415-442.

Alessandri,J.M.,Extier,A.,AlGubory,K.H.,Harbeb y,E.,Lallemand,M.S.,Linard,A.,Lavialle, M.,Guesnet, P. 2011. Influence of gender on DHA synthesis: The response of rat liver to low dietary a-linolenic acid evidences higher o3 D4desaturation indexinfemales.Eur.J.Nutr..Doi: 10.1007/s00394-011-0208-1.

Ali, S. A. Faddah, L. Abdel-Baky, A. and Bayoumi, A. 2010. Protective Effect of LCarnitine and Coenzyme Q10 on CCl4-Induced Liver Injury in Rats.Sci Pharm. 78: 881-896.

Allian, C. C.; Poon, L. S.; Chan, C. S. G.; Richmond, W. and Fu, P. C. 1974.Enzymatic determination of total serum cholesterol. Clin Chem., 20: 470-475.

Bentinger, M. Brismar, K. and Dallner, G. 2007. The antioxidant role of coenzyme Q,Mitochondrion 7; S41-S50. 
Bhagavan HN, Chopra RK. 2006. Coenzyme Q10: absorption, tissue uptake, metabolism an pharmacokinetics. Free Radic Res; 40 (5):445453.

Dumas, B. T., W. A. Watson, and H. G. Biggs. 1971. Quantitative colorimetricdetermination of albumin in serum or plasma." Clin. Chem. Acta: 87-91.

Duncan, D. B. 1955. Multiple range and multiple F tests. Biometrics, 11: 1-42.

Eisenmenger, M., Dunford, N.T., 2008. Bioactive components of commercial and supercritical carbon dioxide processed wheat germ oil. JAm. Oil Chem. Soc 85: 55-61.

El-Beshbishy, H. A.; Singab, A. N. B.; Sinkkonen, J. and Pihlaja, K. 2006. Hypolipidemic and antioxidant effects of Morusalba L. (Egyptian mulberry) root bark fractions supplementation in cholesterol-fed rats. Life Sciences, 78: 27242733.

Forbes, J. M. Coughlan, M. T. and Cooper, M. E. 2008 . Oxidative stress as a major culprit in kidney disease in diabetes. Diabetes, 57: 14461454.

Fossati, P. and Prencipe, L. 1982. Serum Triglycerides Determined Colorimetrically with an Enzyme that Produces Hydrogen Peroxide. Clinical Chemistry, 28: 2077-2080.

Halliwell B and Gutteridge JMC. 1979. Free radical in biology and medicine. 2nd ed. Oxford: Clarendon Press UK.

Hassanein, M.M.M., Abedel-Razek, A.G., 2009. Chromatographic quantitation of some bioactive minor components in oils of wheat germ and grape seeds produced as by-products. J. Oleo Sci., 58: 227-233.

Jayatilleke, E. and Shaw, S. 1993. A high performance liquid chromatographic assay for reduced and oxidized glutathione in biological samples. Anal.Biochem., 214(2): 452-457.

Jenkins, D.J.A., C.W.C. Kenddall, V. Vuksan, L.S.A. Augastin, C.R.D. Mehling, T.R.D. Parker, E. Vidgen B. and et al., 1999. Effect of wheat germ bran on serum lipids: In fluence of particle size and wheat protein J.Am. collegeNutr., 18: 159- 165.

Jonnala, R.S., N.T. Dunford and S. Imark, 2005. Policosanol, tocoferol and phytosterol Composition of wheat extract. IFT Annual Meeting July 15-20, New or leans Louisiana, 54 G-1.

Karatepe, M. 2004. Simulatenous determination of ascorbic acid and free malondialdehyde in human serum by HPLC-UV. Chromatographic Line. 12: 362-365.

Lee, B. M. D. Huang, Y. Chen, S. and Lin, P. 2011. Coenzyme Q10 supplementation reduces oxidative stress and increase antioxidant enzyme activity in patients with coronary artery disease. Nutrition, 1-6.
Leenhardt, F., Fardet, A., Lyan, B., Gueux, E., Rock, E., Mazur, A., Chanliaud, E., Demigne', C., Re'me' sy, C. 2008. Wheat germ supplementation of a low vitamin $\mathrm{E}$ diet in rats affords effective antioxidant protection in tissues. J. Am. Coll. Nutr. 27: 222-228.

Lopez, M. F. 1977. HDL cholesterol colorimetric method.J. of Clin. Chem., 23: 882-896.

Malecka, M., 2002. Antioxidant properties of the unsaponifiable matter isolated from tomato seeds, oat grains and wheat germ oil. Food Chem 79: 327-330.

Marai, I.F.M., Bahgat, L.B., Shalaby, T.H., and Abdel- Hafez, M. A. (2000). Fatting performance, some behavioral traits and physiological reactions of male lambs fed concentrates mixture alone with or without natural clay under hot summer of Egypt. Annals of Arid Zone (India), 39: 449-460.

Mario, A., H. Cesar, B. Laura and G. Luis, 2003. Effect of grape antioxidant dietary fiber on the total antioxidant capacity and the activity of liver antioxidant enzymes in rats. Nutr. Res., 23: 1251-1267.

Mensink, R.P. and M.B. Katan, 1987. Effect of monounsaturated fatty acids versus complex carbohydrates on high - density lipoproteins in health men and woman. Lancet, 1:122-125.

Mohammad, N. S. Arafa, M. H. and Atteia, H. H. 2015.Coenzyme Q10 and fish oil synergistically

Alleviate aluminum chloride-induced suppression of testicular steroidogenesis and antioxidant defense. Free Radical Research. 49(11):1319-34.

Moore, D. M. 2000.Hematology of rabbits. In: B.F. Feldman, J.G. Zinkl and N.C. Jain (eds.) Schalm's Veterinary Hematology.Lippincott Williams and Wilkins, Philadelphia, PA, USA.

Niu, L.Y., Jiang, S.T., Pan, L.J., 2011. Preparation and evaluation of antioxidant activities of peptides obtained from defatted wheat germ by fermentation. J. Food Sci. Technol. doi: 10.1007/s13197-011-0318-z.

NRC, (1977).Nutrient Requirements Center, sixth revised ed. NationalAcademy of Science, National Research Council, Washington,DC, USA.

Papadoyannis, L. N. Samanidou, V. F. and Nitsos, Ch. C. 1999.Simultaneous determination of nitrite and nitrate in drinking water and human serum by high performance anion-exchange chromatography and UV detection. J. Liq. Chrom. Rel. Technol., 22(13): 2023 - 2041.

Paranich, V.A, Cherevko, O.I, Frolova, N.A., Paranich, A.V. 2000. The effect of wheat germ oil on the antioxidant system of animals. Lik.Sprava 2:40-44.

Pari, L. and S. Arumugam, 2008. Effect of grape (Vitisvinifera L.) leaf extract on alcohol induced oxidative stress in rats. Food and Chemical Toxicol., 46: 1627-1634. 
Piras, A.,Rosa,A.,Falconieri,D.,Porcedda,S.,Dess ,M.A.,Marongiu,B.,2009. Extraction of oil from wheat germ by supercritical $\mathrm{CO} 2$. Molecules, 14: 2573-2581.

Potgieter M, Pretorius E, Pepper MS. 2013. Primary and secondary coenzyme Q10 deficiency: the role of therapeutic supplementation. Nutr Rev., 71(3):180-188.

Rahman, S. and Hanna, M. G. 2009. Mitochondrial disease disorders: diagnosis and new treatment in mitochondrial diseases. J NeurolNeurosurg Psychiatry, 80: 943-953.

eitman, S. and Frankel, S. 1957.A Colorimetric Method for the Determination of Serum Glutamic Oxalacetic and Glutamic Pyruvic Transaminases AM. J. Clin. Path., 28: 56- 63.

Roffe, L.; Schmidt, K.; and Ernst, E. 2004. Efficacy of coenzyme Q10 for improved tolerability of cancer treatments: a systematic review. J. Clinic. Oncology, 22: 4418.

Salmeron, J., A. Ascherio, E.B. Rimm, G.A. Colditz, A.L. Wing and W.C. Willet. 1997.
Dietary fiber, glycemic load and risk of NIDDM in men. Diabetes Care, 20: 545-550.

SAS 2004.SAS' Procedure Guide."Version 6.12 Ed."SAS Institute Inc., Cary, NC, USA.

Sohmiya, M.; Tanaka, M.; Tak, NW .; Yanagisawa, M.; Tanino, Y.; Suzuki, Y.; Okamoto, K.; and Yamamoto, Y. 2004. Redox status of plasma coenzyme Q10 indicates elevated systemic oxidative stress in Parkinson's disease. J. Neurolo. Sci.; 223: 161.

TurrensJFandBoveris A. 1980. Generation of superoxyde anion by the NADH dehydrogenase of bovine mitochondria. Biochem J .191: 421-7.

Yalcin, A.; Kilinc, E.; Sagcan, A.; and Kultursay, H. 2004. Coenzyme Q10 concentrations in coronary artery disease. Clinical Biochemistry; 37: 706.

Zacchi, P., Daghero, J., Jaeger, P., Eggers, R.,2006. Extraction/fractionation and deacidification of wheat germ oil using supercritical carbon dioxide. Braz. J. Chem. Eng. 23: 105-110. 


\title{
تأثير زيت جنين القمح و معامل الانزيم Q10 على الاداء الفسيولوجى ودلائل الإجهاد التأكسى على خلايا الخصية فى ذكور الأرانب.
}

\author{
إيمان حامد حلاوة 1 , أحمد أبوالسعود رضوان 1, عبدالكريم إبراهيم محمد السيد 1,عمر عبد الحميد أحمد فريد² \\ 1 \\ 2. قسم الفسيولوجى - الهيئة القومية للرقابة والبحوث الدوائية - الجيزة
}

الهدف من هذه الدراسة هو التحقق من فعالية جرعات زيت جنين القمح ومعامل الانزيم Q10 بالجرعات المنذفضة والعالية على الأداء

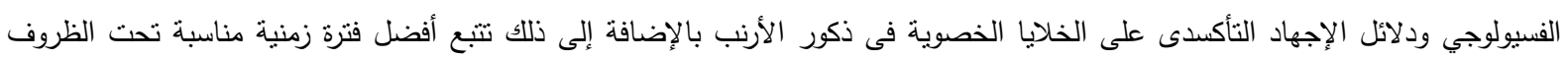

المصرية صيفا.

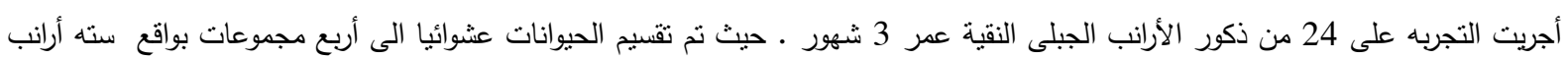
لكل مجموعة ـ المجموعة الأولى كانت المجموعه الضابطة حيث أعطيت 0.5 مل /كجم وزن الجسم من الماء الهاء المقطر , المجموعة الثانية نم

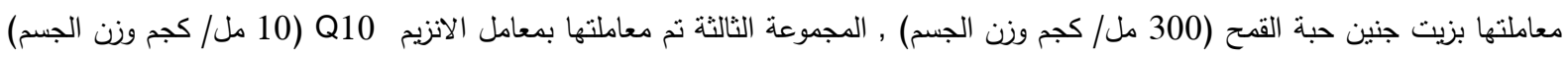

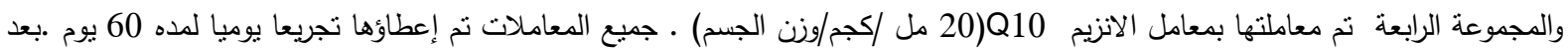

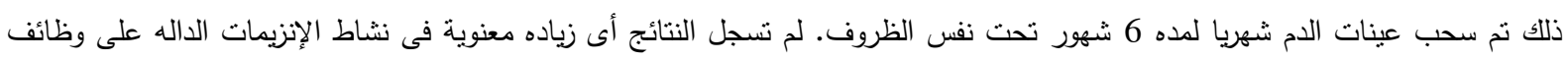

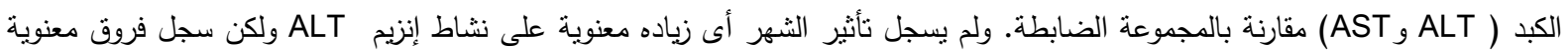

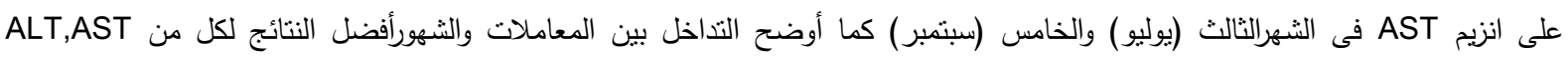

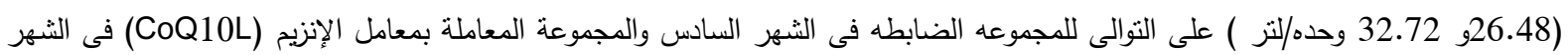
الخامس (سبتمبر) على التوالى.

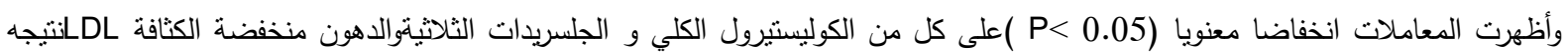
لتعاطى معامل الانزيم

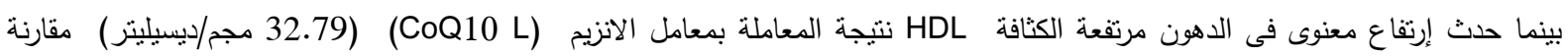

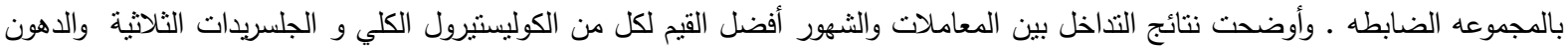

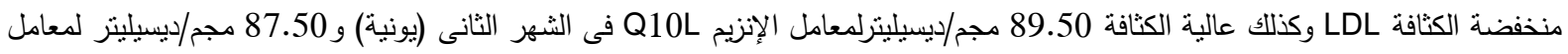

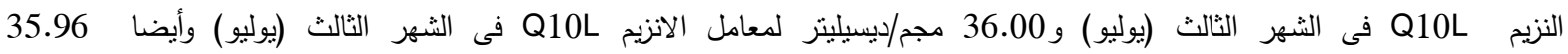
مجم/ديسيليترلمعامل الانزيم

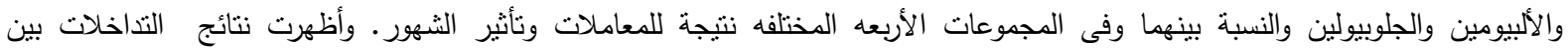
المعاملات والثهور أفضل القيم لبروتينات الدم وكانت للبروتين الكلى والالبيومين والجلوبيولين والنسبة بينهما 7.63 جم/ديسيليتز للمعامل الإنزيم الراني الإنزيم Q10H

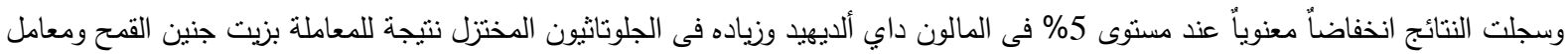
الإنزيج) (Q10). وقد خلصت نتائج الدراسة الحالية الى ان المعامله بزيت جنين القمح ومعامل الإنزيم (Q10) تحسن من القياسات الفسيولوجية وتعمل كمضادات

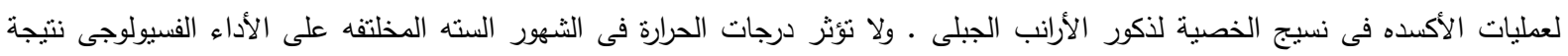
لإلإنخدام مضادات الأكسده. 